\title{
Autocratic Audience Costs: Regime Type and Signaling Resolve
}

\author{
Jessica L. Weeks
}

\begin{abstract}
Scholars of international relations usually argue that democracies are better able to signal their foreign policy intentions than nondemocracies, in part because democracies have an advantage in generating audience costs that make backing down in international crises costly to the leader. This article argues that the conventional hypothesis underestimates the extent to which nondemocratic leaders can be held accountable domestically, allowing them to generate audience costs. First, I identify three factors contributing to audience costs: whether domestic political groups can and will coordinate to punish the leader; whether the audience views backing down negatively; and whether outsiders can observe the possibility of domestic sanctions for backing down. The logic predicts that democracies should have no audience costs advantage over autocracies when elites can solve their coordination dilemma, and the possibility of coordination is observable to foreign decision makers. Empirical tests show that democracies do not in fact have a significant signaling advantage over most autocracies. This finding has important implications for understanding the relationship between regime type and international relations.
\end{abstract}

The idea that democracies have an advantage over autocracies in signaling their intentions is now axiomatic. Audience costs, or the domestic punishment that leaders would incur for backing down from public threats, are thought to increase leaders' ability to convey their preferences credibly during military crises. ${ }^{1}$ These audience costs are typically assumed to be higher in democracies, where democratic institutions increase the likelihood that the leader will actually face punishment for backing down. ${ }^{2}$ Therefore, scholars typically argue that democracies have

I am grateful to Emanuel Adler, Eduardo Bruera, Dara Kay Cohen, Luke Condra, James Fearon, Miriam Golden, Steve Haber, Alex Kuo, Bethany Lacina, David Laitin, Yotam Margalit, Lisa Martin, Kenneth McElwain, Victor Menaldo, Louis Pauly, Maggie Peters, Scott Sagan, Kenneth Schultz, Jake Shapiro, Michael Tomz, three anonymous reviewers, and participants in various Stanford University courses and workshops for their helpful comments. Replication files can be downloaded at $\langle$ www.stanford.edu/ jweeks/research〉.

1. Fearon 1994.

2. See Fearon 1994; Eyerman and Hart 1996; Partell and Palmer 1999; Gelpi and Griesdorf 2001; and Prins 2003. Schultz 1999 also presents evidence consistent with that hypothesis. Slantchev 2006, in contrast, argues that audience costs are higher in democracies only when press freedom is strongly protected. 
an advantage over other regime types in crisis bargaining and making credible commitments more generally.

The conventional wisdom, however, rests on an underestimate of the vulnerability of leaders in nondemocratic regimes. ${ }^{3}$ The stereotypical autocrat in the international relations literature resembles Saddam Hussein or Kim Jong Il crushing domestic rivals and co-opting political institutions. But such despots are a minority among nondemocratic leaders. I develop a logic of autocratic audience costs that takes into account that most authoritarian leaders require the support of domestic elites who act as audiences in much the same way as voting publics in democracies. ${ }^{4}$ The crucial question in generating international credibility is whether the relevant domestic audience can and will coordinate to sanction the leader, and whether the possibility of coordination is observable to foreign decision makers. While the small groups of supporters in autocratic regimes differ from the more inclusive audiences that can punish democratic leaders, autocratic elites can nevertheless visibly remove incumbents when elites have incentives to coordinate to punish the leader, and domestic politics are stable enough that outsiders can infer this possibility. These conditions hold in many autocracies.

Together, these insights about coordination, elite incentives, and visibility have important implications for understanding variation in regimes' abilities to make credible threats and promises. Tests of the effects of regime type on foreign policy must therefore take into account differences between autocracies. I show that existing empirical support for the claim that democracies have a signaling advantage in military disputes results from treating a heterogeneous set of autocracies as undifferentiated. When the group of authoritarian regimes is disaggregated, democracies are not more successful in signaling their resolve than most types of authoritarian regimes. The exceptions are "personalist" regimes and certain types of monarchies, in which the leader has the means to impede elite coordination, as well as new democracies and unstable nondemocracies, where the threat of removal is not observable to outsiders. ${ }^{5}$

I begin with a theoretical discussion of the necessary conditions for generating audience costs. I then argue that autocratic regimes meet these requirements when elites have incentives and ability to coordinate to punish the leader and the potential for punishment is visible to foreign decision makers. Statistical analysis of militarized interstate disputes strongly supports the hypothesis that democracies are not better at generating audience costs than most autocracies.

3. I will use the terms nondemocratic, authoritarian, autocratic, and dictatorial interchangeably, though some scholars attribute more specific meanings to these terms.

4. Bueno de Mesquita et al. 2003.

5. See Geddes 2003. Chehabi and Linz 1996 describe a similar type of regime, which they term "sultanistic." 


\section{The Logic of Audience Costs}

The audience costs proposition suggests that states can send informative signals about their resolve by making public threats in international crises. ${ }^{6}$ Because leaders could suffer domestic consequences for making a threat and then not carrying it out, they are able to create potential domestic consequences for backing down. This in turn gives their threats greater credibility.

Since the concept of audience costs was first articulated by Fearon, scholars have assumed that democracies have an advantage in generating audience costs, and hence an advantage in signaling resolve. ${ }^{7}$ Although Fearon does not deny that some autocrats might be able to create audience costs, he proposes a democratic advantage since democratic leaders cannot control ex post punishment for backing down from a threat. The risk that reneging will be punished domestically, in turn, renders the threat more credible internationally. In contrast, dictators are assumed to exert greater control over their tenure, implying an inability to credibly jeopardize their political futures. Thus, "democracy" is often used in this literature as shorthand for accountability. ${ }^{8}$ A recent body of work has found empirical support for the hypothesis that democracies have a signaling advantage attributable to audience costs. ${ }^{9}$

But the possibility that authoritarian regimes exhibit predictable variation in their ability to generate audience costs, and moreover, that democracy is not necessary for generating audience costs, merits further attention. Elections and democratic institutions are only one way in which domestic groups can coordinate to hold leaders accountable. In order to reevaluate prevailing arguments about how audience costs vary across political systems, it is helpful to clarify the logic of audience costs.

A leader's ability to generate domestic political costs is influenced by three central factors. First, audience costs require that a domestic political audience has the means and incentives to coordinate to punish the leader. Second, domestic actors must view backing down after having made a threat as worse than conceding without having made a threat in the first place. Third, outsiders must be able to observe the possibility of domestic sanctions for backing down. Nondemocratic states vary greatly with respect to these three variables.

6. See Schelling 1963; and Fearon 1994.

7. Fearon 1994.

8. See, for example, Guisinger and Smith 2002, 180. Other researchers have taken a more agnostic view, though they still group regimes according to the level of democracy; see Chiozza and Goemans 2004 .

9. See Eyerman and Hart 1996; Partell and Palmer 1999; Gelpi and Griesdorf 2001; and Prins 2003. In addition, Schultz's finding that democracies are less likely to be resisted in international crises can be interpreted as evidence in favor of higher democratic audience costs, though Schultz presents a distinct theoretical mechanism where resolve is revealed through public party competition; see Schultz 1999 and 2001a. 


\section{Domestic Actors Can and Will Coordinate to Sanction the Leader}

The first factor influencing audience costs is whether a domestic audience can and will punish the leader for backing down from a threat, the ultimate punishment being removal from office. Fearon does not lay out explicitly when a domestic group qualifies as an audience, though he argues that "kings, rival ministers, opposition politicians, Senate committees, politburos, and, since the mid-nineteenth century, mass publics informed by mass media" have all counted as relevant audiences historically. ${ }^{10}$ One can infer that the essential feature of a domestic audience is its ability to sanction the leader.

Building on this logic, the working hypothesis has been that leaders are much more vulnerable to domestic punishment in democracies than in nondemocracies, due to the existence of self-enforcing institutions specifically designed to hold leaders accountable. In nondemocracies, in contrast, sanctioning the leader is thought to be a much riskier and costlier endeavor. International relations scholars have therefore tended to assume that autocratic leaders are largely unaccountable to domestic groups. ${ }^{11}$

However, scholars of comparative politics have long argued that even without democratic institutions, autocratic leaders depend on the support of domestic groups to survive in office. ${ }^{12}$ The difference is that in authoritarian regimes, these influential groups usually represent fewer societal interests than in democratic regimes. This insight has been integrated into some of the recent international relations literature, though not the literature on audience costs and the ability to convey resolve. ${ }^{13}$

The Costs of Coordination. In understanding audience costs, the democraticautocratic distinction is only a rough proxy for the ability of domestic groups to sanction leaders for missteps such as backing down. In any political system, punishing a leader can be viewed as a coordination problem between individuals or groups in society. ${ }^{14}$ What, though, is the nature of this coordination problem, and how do members of different societies solve it?

The fundamental challenge facing any individual-no matter what the political regime-is how to determine whether the benefits of participating in the removal of the leader outweigh the potential costs. The first source of costs is the individual's expectation that the individual will be punished for moving to oust the incumbent. This depends on whether the individual thinks the ouster will be successful, which

10. Fearon 1994, 581.

11. As McGillivray and Smith put it, "ousting authoritarian leaders is more costly [than ousting democratic leaders], often requiring social unrest and possibly even civil war"; McGillivray and Smith $2000,815$.

12. See Geddes 1999 and 2003; Bueno de Mesquita et al. 1999 and 2003; and Haber 2006.

13. See Goemans 2000; and Bueno de Mesquita et al. 2003.

14. Weingast 1997. 
depends on whether the individual can learn reliable information about other individuals' intentions.

More specifically, individuals deciding whether to participate in the ouster of a leader face a strategic situation similar to the stag hunt, a classic coordination game. ${ }^{15}$ Imagine that two individuals face an incumbent that they would both prefer to see replaced, all else equal. Both individuals must decide whether to oust or not-this could take the form of casting a ballot, protesting in the streets, or obeying a new leader rather than the incumbent.

The ouster will be successful only if both individuals (or, more realistically, many individuals in a multiplayer game) choose to oust. This situation most strongly resembles a coordination game rather than a prisoner's dilemma because no individual wants to be the "odd one out"; her strategy depends on her expectations about the other players' actions. If everyone else ousts, the individual prefers to oust too, because she can then capture the higher payoff from her preferred outcome of replacing the leader, as well as gaining influence under the new leadership. If the individual cannot trust that enough other players will oust, however, she is better off lying low (catching rabbits). The structure of the game also captures the idea that the payoffs to lying low alone/catching rabbits alone are higher than the payoffs of ousting alone/hunting stag alone.

Given this strategic situation, the outcome depends on the players' beliefs about what the other player(s) will do. In one-shot coordination games in which players care only about their own payoffs, and do not face any additional costs for voicing their preferences, simple communication is usually enough for successful coordination because players have no incentive to lie about their intentions. In such a situation, two people who preferred to oust would simply say so, and would then execute their plan.

In politics, however, coordination is more difficult because individuals may face external incentives to conceal their true preference. Most importantly, individuals may fear retaliation from the incumbent for voicing opposition. This fear will be heightened with increases in the leader's ability to monitor individuals and punish the disloyal. As the incumbent's ability to monitor and punish rises, individuals will find it more preferable to conceal their preference to oust-or, in the words of Kuran, to engage in preference falsification, voicing a public preference that diverges from their private preference. ${ }^{16}$ In sum, when the incumbent can monitor and punish on the basis of publicly expressed preferences, coordination becomes difficult even if all players' "underlying" preference is to oust.

Throughout history, societies have used a number of different methods to limit the leaders' ability to use monitoring and punishment to impede coordination. For

15. See Menaldo 2006, for a similar logic focusing on the importance of constitutions in authoritarian regimes.

16. Kuran 1991. Kuran's analysis of preference falsification and revolutionary bandwagoning in the context of the Eastern European revolutions is closely related to the logic I develop here. However, my analysis is focused less on the rapidity of coordination than variation in coordination across regime types. 
example, in democracies, legal protections for freedom of speech and assemblybacked by courts that protect these rights_-preclude the incumbent from monitoring and punishing citizens for voicing opposition. Thus, most individuals in democracies live in an equilibrium in which they can express their preferences openly, removing the leader when enough of them agree to oust.

In nondemocratic regimes, on the other hand, the leader and elites collaborate to explicitly preclude participation by the population. They do this, of course, by making it costly for citizens to coordinate, punishing those who criticize the regime (either individually, or by forming political organizations) through imprisonment and other punishment. However, nondemocracies vary greatly in the extent to which regime insiders can coordinate to punish the leader, rendering regime elites an effective audience. While most citizens cannot challenge the leader, elites with key positions in the regime can still oust leaders if they can solve their coordination problem. ${ }^{17}$ It is this variation in nondemocracies that has typically been overlooked by international relations scholars.

The question now becomes to what extent the incumbent can monitor and punish regime insiders for expressing disapproval. First, regimes vary greatly in the extent to which leaders control the intelligence organs, allowing them to monitor elite opposition. For example, while Joseph Stalin, Saddam Hussein, and Augusto Pinochet used their control over intelligence to locate internal dissent, intelligence organs in other regimes are accountable to collective bodies such as juntas or politburos. The ousting of Soviet premier Nikita Khrushchev in 1964 was not carried out until its planners were certain that they had secured the cooperation of the KGB (Soviet secret police) majorities in the Central Committee and Presidium, and officials spanning the territorial party apparatus. It was the relative independence of the KGB from Khrushchev's control, and the fact that Khrushchev did not have his own police forces, that kept him from learning of the plans and punishing the plotters. ${ }^{18}$

Regimes also vary in the extent to which the leader can punish the disloyal. While Stalin, because of his control over the secret police, was able to use force to fire, arrest, imprison, and kill officials as he saw fit, the Communist Party after Stalin's death strongly limited the power of the KGB to try and sentence the accused. After 1953, trial and sentencing were carried out by civilian bodies out of Khrushchev's and Leonid Brezhnev's exclusive control.

In addition to preventing elite coordination through monitoring and punishment, a leader may also use positive incentives to either encourage elites to inform on other elites, or to pay off elites so that their payoffs to ousting are less than the payoffs to lying low and receiving promotions and other perks. Bueno de Mesquita and colleagues suggest that this is precisely why leaders of small winning-coalition societies focus on providing private rather than public goods. ${ }^{19}$

17. Haber 2006.

18. Tompson 1991, 1108.

19. Bueno de Mesquita et al. 2003. 
But rewards are not the focus of the subsequent analysis for two reasons. First, if regime insiders have sufficient freedom from monitoring and punishment to allow them to coordinate, they may work together to limit the individual leader's control over government resources, checking the leader's ability to buy people off at will. This is precisely what has occurred in many single-party regimes, such as Tanzania under Julius Nyerere, where rules have limited not only the leader's financial discretion but also the maximum pay government officials could earn. Second, even if the leader can use private payoffs to buy off dissatisfied elites, this still entails a real cost to the leader. If the leader backs down from a threat, incurring the dissatisfaction of elites, the leader will be forced to divert extra resources to buy their continued loyalty after backing down, entailing tangible additional costs to the leader's future survival.

In sum, regimes vary in the extent to which the leader has the power-typically backed by force-to monitor and punish the leader's peers. In regimes in which intelligence and security organs are monitored by a collective rather than an individual incumbent, the coordination dilemma between elites can be solved by simple communication. The leader will find it much more difficult to detect criticism and punish elites for voicing criticism.

The Costs of Leader Turnover to the Ruling Group. In the previous section I argued that coordination to punish leaders is possible in both democracies and autocracies, unless the leaders have the monitoring and coercive capacities to punish individuals who oppose them. A closely related proposition is that a leader's domestic vulnerabilities do not translate into accountability unless the fate of the audience is decoupled from the fate of the leader. Otherwise, the payoffs to ousting will be lower than the payoffs to lying low.

In democracies, the credibility of threats against the leader is taken for granted, since the welfare of voters-and some elites-is usually not directly influenced by the identity of the leader (though voters may have preferences over the policies of different leaders). In democracies, the overall strength of the regime has little to do with the identity of the leader: the U.S. federal government does not become less legitimate or powerful when a new president takes office.

Nondemocracies, however, vary greatly in terms of how leadership turnover affects elites' welfare. In some political systems, elites' fates are so closely tied to the fate of the leader-for example, through blood relation or because the elites have no independent base of support or power-that they will view keeping an inferior incumbent as favorable to replacing him with a new leader and risking losing office themselves. Perhaps this is why many dictators, including Saddam Hussein and Kim Il Sung, filled top offices with relatives and other loyal associates. Similarly, many of Ethiopian Emperor Haile Selassie's most trusted ministers were "plebeians" whom he had personally plucked out of the hinterland and raised to high office-supporters who therefore had everything to lose should Selassie fall from power. In all likelihood, this dimension is not separate from the leader's control of monitoring and punishment: more powerful leaders are able to 
exert greater control over hiring and firing, filling high office with those who depend on them completely for their livelihood.

In contrast, in other authoritarian systems, the leader has much less control over who holds high office. Most high officials do not serve purely at the pleasure of the individual leader, and can expect to continue in politics even if the leader is removed. In the Soviet Union after Stalin, party officials from across the USSR elected the Central Committee, which in turn chose the membership of the Politburo. Accordingly, when Khrushchev was ousted, nearly all top officials retained their positions, as their political careers were not tied personally to Khrushchev. Similarly, in military regimes, military hierarchies rather than personal ties play an important role in promotion to and maintenance of high office. In the Argentine military junta between 1976 and 1983, junta members ousted three separate incumbents. While the regime was able to exert its will on the population indiscriminately, no single leader was ever able to eliminate rivals from the regime and stack it with cronies lacking incentives to oust him. ${ }^{20}$

\section{Domestic Audiences Disapprove of Backing Down}

The second factor influencing audience costs concerns how audiences view leaders who back down from threats. For public threats to be informative through an audience costs mechanism, backing down must be costly for the leader.

There are at least two plausible reasons why domestic audiences might impose audience costs on leaders who back down. The first reason is that bluffing hurts the leader's international reputation, and hence the leader's future ability to bargain effectively; it is therefore in the audience's interest to replace the leader and regain credibility. ${ }^{21}$ Even actors who actually supported the decision to back down will, ex post, have incentives to remove leaders if they anticipate that this will help the country bargain more effectively in the future. An alternative reason that audiences may disapprove is that a failed bluff conveys information about the leader's competence more generally. ${ }^{22}$ Regardless of the rationale, experimental evidence suggests that subjects more strongly disapprove of leaders who back down after making threats, compared to leaders who made no threat in the first place. ${ }^{23}$

For the purposes of predicting variation in audience costs across political systems, then, the question is whether members of domestic audiences in democratic regimes are on average more likely to value credibility or competence than audiences in various types of autocratic regimes. There is no clear theoretical reason that this would be the case. Therefore, the second key precondition for audience costs is likely to be present not only in democracies but also in autocratic regimes.

20. Linz and Stepan 1996, 190-94.

21. See Fearon 1994; McGillivray and Smith 2000; and Guisinger and Smith 2002.

22. Smith 1998.

23. Tomz 2007. 


\section{Outsiders Can Observe the Leader's Insecurity}

Finally, the last requirement for sending credible signals via audience costs is that the target state perceives that the leader could face domestic sanctioning. Here, the critical question is whether politics are stable enough for outsiders to determine whether the leader faces an accountability group in practice. In regimes with new democratic institutions such as parliaments or elections designed to hold the leader accountable, it remains unclear whether the leader and domestic groups will play by the official "rules of the game" until the rules have been tested. Similarly, in unstable nondemocratic regimes, observers will have trouble discerning whether the leader shares control of the state apparatus with elites, or rules alone. Thus, leaders of states that have recently undergone institutional change-whether nominally democratic or not-will find it difficult to publicly and credibly jeopardize their political futures.

In stable regimes, in contrast, foreign decision makers can typically determine whether the leader rules alone, or is plausibly accountable to parliament, voters, or groups of elites such as politburos and juntas. Similarly, they can see whether the leader conducts purges and repeated firings of high-level officials, or is forced to accept the existence of potential rivals in government. In the Khrushchev-era Soviet Union, for example, Western media ran a series of articles detailing Khrushchev's political insecurity both before and after events such as the Cuban Missile Crisis. ${ }^{24}$ Moreover, even if the individual leader is new in office, if the regime is relatively stable, foreigners can observe whether the leader's predecessors were removed from office by fellow elites, or lost office only through death or violent coups by regime outsiders. For example, during the Argentine military junta of the late 1970s and early 1980, foreign newspapers reported about individual leaders' support from within the officer corps and three-man junta and could easily learn details of how successive leadership turnovers occurred. ${ }^{25}$

The visibility condition described here is quite undemanding: the only requirement is that the opposing state knows that the leader faces a real probability of domestic sanctioning. Recall that the "audience cost" does not arise because domestic audiences disagree with their leaders' policy. Rather, the cost is imposed because leaders either hurt their international credibility or reveal their incompetence. For example, for democracies to have higher audience costs on average does not require

24. Published before the Cuban Missile Crisis, "Is Mr. Khrushchev Pressed By Military Clique?" (London Times, 5 September 1961) suggests that Khrushchev was forced to listen to military influences in the elite. After the crisis, "Moscow Rallies Support for Mr. Khrushchev's Policy" (London Times, 6 November 1962) reports that Khrushchev was facing domestic criticism for removing the missiles. "Mr. Khrushchev Reported to Be Facing a Crisis" (London Times, 2 April 1963); "Mr. Khrushchev Regains Some Support" (London Times, 30 April 1963); and "Mr. Khrushchev to Keep His Job" (London Times, 20 May 1963), detail the rise and fall of the Soviet leader's political support—and imply that whether or not he kept his job was not in his own hands.

25. See "President Videla Is Confirmed for Second Term" (London Times, 4 May 1978, 6); Tony Emerson, "Argentina's Next President May Face Two Crises" (London Times, 6 October 1980, 5); and Patrick Knight, "Viola Replaced in Argentina by Junta Rivals" London Times, 12 December 1981). 
that outsiders read public opinion polls about the government's policy statements. Rather, threats by democracies are credible because outsiders observe that domestic groups could punish the leader. Similarly, outsiders do not need information about authoritarian elites' policy preferences as long as they know that elites have the means and incentives to punish the leader if necessary.

This relatively permissive visibility condition contrasts with alternative theories predicting that democracies are better at signaling resolve, such as Schultz's theory about the information conveyed by opposition parties during crisis bargaining. ${ }^{26}$ Schultz argues that the office-seeking motivations of opposition parties lead them to decide strategically whether to support or oppose their government's threat to use international force, based on their expectations about the outcome. When the opposition stands behind its government, this increases the target's belief that the threat is genuine. ${ }^{27}$ For Schultz's mechanism to work, a polity must allow political competition that is legitimate, institutionalized, public, and in which opposition parties have access to policy-relevant information. This involves a higher informational requirement than an audience costs logic, which requires only that outsiders believe that domestic groups in the challenging country could make it costly for the leader to back down. Rather, the logic I develop suggests that open party competition and free mass media are not required for the generation of audience costs. Rather, regime stability is the crucial condition as this allows outsiders to learn the rules of the domestic political game.

\section{Variation in Audience Costs Across Autocratic Regimes}

I argue in the section above that there are three prerequisites for generating audience costs: whether domestic actors have the means and desire to coordinate to oust the leader; whether outsiders can observe that an audience can punish the leader; and whether the audience views backing down negatively. More specifically, elites will have greater incentives to coordinate if the leader cannot monitor and punish defection through personal control of intelligence and security organs and does not control political appointments. In turn, foreign observers can infer the possibility of audience costs if the regime is relatively stable, allowing them to observe whether elites have coordinated in the past. Moreover, I argued that nondemocratic audiences have no reason to view backing down more favorably than democratic audiences. The logic implies that a leader's ability to generate audience costs does not depend on features of liberal democratic regimes, such as

26. Schultz 2001a.

27. Like the idea that audience costs are higher in democracies, Schultz's theory predicts that on average, threats issued by democratic challengers should be more credible than threats issued by nondemocratic challengers. 
an inclusive electorate, voting mechanisms, or free speech. As long as the audience knows that the leader made a threat and backed down-and this would be difficult to disguise from regime insiders even in the absence of a free news mediafreedom of speech and the political engagement of the masses are not required.

The proper way to predict variation in audience costs, therefore, is to distinguish between regimes according to the remaining conditions noted above: whether domestic elites can and will coordinate to oust the leader, and whether foreign decision makers can observe that the leader faces domestic accountability. This section disaggregates regimes based on whether they fulfill the coordination and visibility criteria.

Geddes's classification of dictatorships is one source of useful data in this regard. ${ }^{28}$ Geddes argues that typically, "the greatest threat to the survival of the leader in office - though not necessarily to the survival of the regime-comes from inside [the] ruling group, not from outside opposition." ${ }^{29}$ She classifies countries as military regimes, single-party dictatorships, personalist regimes, and hybrids of these types according to their "different procedures for making decisions, different characteristic forms of intra-elite factionalism and competition, [and] different ways of choosing leaders and handling succession." 30

Fortunately, the rules Geddes used to generate her categorization of autocracies allows one to use the regime type data to test hypotheses about audience costs. Geddes codes regimes by aggregating the answers to three distinct groups of yes/no questions. ${ }^{31}$ Each group of questions reflects the characteristics of one particular regime type. Countries are assigned to categories based on which group of questions receives the most "yes" answers. Many of the questions relate directly to the factors that I argue reflect whether or not elites can coordinate against the leader: whether the leader controls the security organs, giving the leader power to punish dissent, and whether the leader controls appointments, allowing the leader to place only trusted associates in influential positions.

Importantly, the coding criteria for both single-party and military regimes indicate that the leader does not usually control appointments or security organs in such regimes. Single-party regimes are "those in which the party had some influence over policy, controlled most access to political power and government jobs,

28. Geddes's categorization has also fruitfully been used in the crisis literature, in analyses of types of dictatorships and their conflict behaviors. See, for example, Peceny, Beer, and Sanchez-Terry 2002; Peceny and Beer 2003; and Kinne 2005.

29. Geddes 2003, 50. A different measure that would be useful is the Bueno de Mesquita et al. 2003 measure of the size of the winning coalition, or the relative size of the group whose support is essential to the survival of the incumbent. Powerful leaders may have incentives to reduce the size of the audience they face, filling positions only with loyal supporters. A small winning coalition could therefore be evidence of a more powerful leader. However, Bueno de Mesquita and colleagues explicitly assume that military regimes have particularly small winning coalitions, so their measure would not be a direct test of my hypothesis for all regime types.

30. Geddes 2003, 48-49.

31. Ibid., 225-27. 
and had functioning local-level organizations." 32 In Geddes's single-party regime, domestic institutions such as politburos are not "rubber-stamp" organizations composed of associates or relatives selected by the leader. Rather, single-party regimes often hold intraparty competitive elections for certain offices, and factions or cadres may form around policy issues and competition for important offices. Among the coding criteria for single-party regimes are whether "none of the leader's relatives occupy very high government office" and whether the "party control[s] access to high government office." ${ }^{33}$ Since elites in single-party regimes rise through the ranks of the party and are often elected by other party members to high office, most of them are not personally connected to the leader and have little reason to think they will lose office if the leader is ousted. Moreover, foreigners can observe all of these facts when single-party regimes are stable.

Military regimes, according to Geddes, are "governed by an officer or retired officer, with the support of the military establishment and some routine mechanism by which high-level officers could influence policy choice and appointments." ${ }^{34}$ Mechanisms for leadership transfer typically involve juntas or military councils of officers. Furthermore, the military hierarchy is preserved and the army stays under the control of the military rather than the leader. Countries are more likely to be coded as military regimes if "merit and seniority [are] the main bases for promotion, rather than loyalty or ascriptive characteristics" and if the leader has "refrained from having dissenting officers murdered or imprisoned." ${ }^{35}$ Moreover, because most elites in military regimes are not personally connected to the incumbent, they can expect to stay in power if the leader falls. Finally, in stable military regimes, these facts are observable to foreigners. According to Geddes's coding, then, there is no reason to think that the threat of punishment should not be credible in both military and single-party regimes.

Personalist regimes, in contrast, most closely reflect the conventional wisdom about nondemocracies: there is no domestic audience that can effectively coordinate to sanction the leader. This is for two reasons: the leader has the means to punish internal critics, and the fate of elites is intimately connected to the leader's survival in office, reducing their incentives to punish leaders. For example, among the criteria for personalist regimes are whether the leader "personally control[s] the security apparatus" and whether "access to high office depend[s] on the personal favor of the leader." Personalist leaders therefore can discipline elites much more harshly than leaders of regimes where power is less concentrated. Not only can these leaders use their control of security organs to arrest, demote, imprison, or even kill critics but they can also use more subtle tactics unavailable to leaders who have less control over political appointments. Pinochet and other dictators

32. Ibid., 72 .

33. Ibid., 225-27.

34. Ibid., 72.

35. Ibid., 226. 
often used their control over appointments to frequently rotate elites through different offices so that they did not have an opportunity to build an independent power base.

Moreover, elites in personalist regimes will find it much less appealing than elites in other regimes to remove their leader. The fate of elites is typically tied closely to that of the incumbent. As Bratton and van de Walle note, because regime insiders in personalist states are

Recruited and sustained with material inducements, lacking an independent political base, and thoroughly compromised in the regime's corruption, they are dependent on the survival of the incumbent. Insiders typically have risen through the ranks of political service and, apart from top leaders who may have invested in private capital holdings, derive livelihood principally from state or party offices. ${ }^{36}$

For elites in personalist regimes, keeping a poor leader in office is more often preferable to ousting the incumbent and risking one's own career; the leader does not face a credible threat of removal.

Finally, foreign decision makers can observe that personalist rulers face no consistent threat of punishment. For example, while followers of Soviet or Argentine politics were aware of rivalries, factions, and leadership turnovers, those interested in North Korean politics had no reason to believe that Kim Il Sung faced any real internal challenges. Instead, they learned that the "Great Leader" was the "unchallenged ruler" of his country, conducted massive purges of elites (once purging seventeen members of the twenty-six-member Politburo), and placed numerous relatives in positions of power. ${ }^{37}$ In sum, the leader's concentration of power, and elites' dependence on the incumbent for their livelihood make any attempt to coordinate on the part of domestic elites both dangerous and difficult to conceal.

In addition to military, single-party, and personalist regimes, there are two classes of nondemocratic regimes not coded by Geddes meriting discussion: monarchies, and nondemocracies that do not meet Geddes's criterion of having been consolidated for three years. ${ }^{38}$

The first group of nondemocracies omitted by Geddes includes monarchies such as Jordan, Morocco, Saudi Arabia, and Iran until 1979. While Geddes does not code monarchies, and therefore does not provide information about whether the leader controls the security apparatus or appointments, scholars have argued that a crucial determinant in whether or not the leader is accountable is whether the mon-

36. Bratton and van de Walle 1994, 464. Cited also in Geddes 2003, 60.

37. "Marshal Kim Tightens Grip on N Korea in Leadership Changes" (The Times, 18 November 1970, 7).

38. In addition, Geddes does not code post-revolution Iran and post-Soviet republics such as Turkmenistan, Tajikistan, Kyrgyzstan, Uzbekistan, and Kazakhstan. These are dropped from the empirical analysis below. 
arch rules alone, or with the assistance of the extended ruling family. ${ }^{39}$ Herb distinguishes between dynastic monarchies-regimes in which "the family forms a ruling institution," and nondynastic monarchies in which the ruler rules alone. ${ }^{40}$ In dynastic monarchies, Herb argues, members of the family share an interest in maintaining the continued health of the dynasty, and cooperate to keep the leader in check. The leader does not control appointments; instead, family members rise to high office through seniority, and the "king or emir cannot dismiss his relatives from their posts at will" (though as the head of the regime, he does play a major role in appointments). ${ }^{41}$ While Herb does not explicitly discuss the extent to which the individual leader controls the security apparatus, he argues that "the family has the authority to remove the monarch and replace him with another member of the dynasty." 42 Importantly, dynastic monarchies differ from personalist regimes in that although family members hold high office, they do not hold their position at the whim of the leader and will retain power and influence even if the leader is removed. Regime insiders therefore will have incentives to remove the leader if he or she endangers the prestige or authority of the dynasty.

In contrast, nondynastic monarchies tend to more closely resemble personalist regimes. Although family members within nondynastic regimes can expect that one of them will inherit the throne, they are excluded from holding important posts in the regime. Rather, the king can promote loyal followers to high positions, similar to his personalist counterparts. Moreover, leaders of nondynastic regimes such as the Shah of Iran typically have "solid control over the state and its coercive apparatus" that, according to the logic I laid out earlier, should allow them to impede coordination by elites. ${ }^{43}$ In sum, leaders of dynastic regimes should be able to generate audience costs, while nondynastic monarchs, like personalists, will find it difficult to generate audience costs since they face no true accountability group.

Geddes also omits country-years that do not meet her classification of a "regime," or "sets of formal and informal rules and procedures for selecting national leaders and policies." 44 Therefore, she does not code regimes that ultimately did not last for at least three years, though she does include the first three years of regimes that did eventually last for three years or more. Here, I code as nondemocratic interregna any regime that experienced a substantial change in their Polity IV score within the last three years and also has a Polity score below 7 in the year in question. ${ }^{45}$ This means that some country-years originally categorized as military, personalist, or single-party by Geddes are now coded as nondemocratic interre-

39. Herb 1999. See also Anderson 1991.

40. Herb 1999, 8.

41. Ibid., 33.

42. Ibid., 238.

43. Ibid., 219. While many nondynastic regimes are "constitutional monarchies," moreover, their parliaments are typically "little more than an arena in which politicians divided up, and fought over, the spoils of rule"; ibid., 211.

44. Geddes 2003, 70.

45. Marshall and Jaggers 2002. 
gna; this makes sense since observers at the time could not have known that the regime would ultimately last. In terms of elite coordination, these regimes are a grab bag. Some leaders will not have had enough time to gain control over the coercive apparatus; others will have risen to power after a civil war or revolution and will enjoy substantial control. However, as a group, these regimes will suffer in terms of the visibility of audience costs. The rules of the game will not be clear to outsiders (nor, probably, to insiders), so foreigners will have a difficult time judging whether the leader truly faces domestic accountability. For this reason, nondemocratic interregna will have difficulty generating audience costs.

Similar to the autocratic interregna described above, there are new democracies, or regimes that are democratic according to Polity but have not yet persisted for three years. Since Geddes codes regime type for authoritarian regimes that are ultimately in existence for only three years, one must be careful to treat democracies similarly. Otherwise, the "democracy" category would include a disproportionate number of young or unstable regimes compared to the autocratic categories. This final category is similar to nondemocratic interregna in that while domestic groups may sometimes be able to depose the incumbent, foreigners will find it very difficult to assess whether the new laws reflect the true rules of the game. ${ }^{46}$ Like nondemocratic interregna, new democracies do not meet the visibility condition and therefore their leaders will have difficulty generating audience costs.

Finally, there are mixed nondemocracies that fit none of the criteria described above: they are not stable democracies or new democracies, have not experienced regime change in the last three years, and yet their autocratic regime type was not coded by Geddes. This group of regimes includes the post-Soviet states, Iran, South Africa under apartheid, and a number of anocracies-regimes where participation is only partially regulated. While this group represents a diverse set of regimes, there is no reason to think that individual leaders have inordinate capacities to monitor and punish elite criticism in these states. Moreover, since all regimes in this category have experienced regime stability for three years or more, the leader's political insecurity should be visible to outsiders. Mixed regimes should not have a disadvantage in generating audience costs compared to other stable regimes in which elites can coordinate.

\section{Quantitative Analysis}

The previous section provides a theoretical rationale for reexamining the relationship between regime type and audience costs, instead classifying regimes according to the likelihood of elite coordination and whether this is visible to foreign decision makers. Below I present empirical tests of the predictions developed above, namely that democracies, single-party states, military regimes, and dynastic mon- 
archies should all be able to generate audience costs. In contrast, personalist leaders and nondynastic monarchs can impede elite coordination, while nondemocratic interregna and new democracies do not meet the visibility condition. Therefore, personalists, nondynastic monarchs, and leaders of both democratic and nondemocratic regimes that have not persisted for at least three years should be significantly less able to generate audience costs than other regimes.

The strategic nature of crisis behavior presents methodological challenges when testing for the existence of audience costs. As Schultz notes, leaders have incentives to avoid precisely those situations in which one would expect to observe these costs directly. ${ }^{47}$ Therefore, in order to test hypotheses about audience costs, one must look to dependent variables that take into account leaders' strategic decision to avoid situations in which backing down would be likely. Fearon points out that one observable implication of states' ability to make informative threats, for example by generating audience costs, is that threats by such states will on average be more effective than threats by states without such an advantage. ${ }^{48}$ Schultz uses this insight to argue that if democracies are systematically more able to transmit information about resolve, this should be reflected in lower rates of resistance to democracies' threats. ${ }^{49}$

The Militarized Interstate Disputes (MID) data set contains a record of every interstate threat or use of military force since $1816 .^{50}$ An MID is coded when an initiating state uses or explicitly threatens force against a target state. Targets sometimes respond with a militarized action of their own, while other times they choose to forgo a military response. To capture whether some types of initiators encounter more resistance from their targets than other initiators, Schultz analyzes the variable RECIP, which has a value of 1 if the target state responded with a militarized action, and 0 if the target state made no militarized response to the challenger's threat or use of force. ${ }^{51}$ This provides an indication of whether the target was hesitant to escalate the crisis because it thought the threat was genuine. On average, one should expect that initiators with a high ability to generate audience costs should be less likely to face resistance than states with a low ability to generate audience costs. ${ }^{52}$ Accordingly, democracies, single-party regimes, military regimes, and dynastic monarchies should face lower reciprocation rates than personalist regimes, nondynastic monarchies, nondemocratic interregna, and new democra-

47. Schultz 2001b.

48. Fearon 1994.

49. Schultz 1999, and 2001a.

50. See Ghosn, Palmer, and Bremer 2004; and Jones, Bremer, and Singer 1996.

51. Schultz 1999 and 2001a.

52. It bears reemphasis that there are alternative mechanisms through which democracies may be able to generate credible threats. Schultz 1999 and 2001a argues that democracies generate more credible threats because public debate by opposition parties allows the government to signal its resolve more effectively. Both higher audience costs and the existence of public opposition parties imply corresponding lower rates of resistance to threats, though the model developed by Schultz would not be able to explain why single-party or other authoritarian regimes would generate credible threats since public opposition is typically banned. 
cies. Moreover, there is no reason to expect that democracies should encounter lower reciprocation rates than any of the remaining regime types meeting the coordination and visibility conditions.

TABLE 1. Target reciprocation rate by regime type of challenger

\begin{tabular}{lrr}
\hline Challenger & $1816-99$ & $1946-99$ \\
\hline DEMOCRACY & $(574) .38$ & $(358) .41$ \\
NONDEMOCRACY & $(1,967)^{.49}$ & $(1,224)$ \\
Total & .51 \\
Chi-square p-value & $(2,541)$ & $(1,582) .49$ \\
\hline
\end{tabular}

Note: The number of observations is in parentheses.

Table 1 depicts a first cut at the data: targets' rate of reciprocation conditional on whether or not the challenger is a democracy. ${ }^{53}$ This comparison between democratic and all nondemocratic regimes represents the typical way the effects of regime type are operationalized in the conflict literature. Here, democracies are defined as regimes scoring 7 or higher on the combined Polity IV scale and having persisted for at least three years, though similar patterns hold when new democracies are included. ${ }^{54}$ Column (1) includes all crises since 1816; column (2) represents the 1946-99 period, for which Geddes codes authoritarian regime type.

This table indicates that, in both time periods, democratic challengers are met with lower rates of resistance than challengers of other regime types. In both periods, a chi-square test indicates that one can reject the null hypothesis that there is no relationship between democracy and the rate of reciprocation of target states.

The next step is to analyze rates of target reciprocation after disaggregating autocratic regime types. I first generate variables according to Geddes's coding of SINGLE-PARTY, PERSONALIST, and MILITARY regimes. I also generate categories for DYNASTIC MONARCHY, NONDYNASTIC MONARCHY, NONDEMOCRATIC INTERREGNA, and NEW DEMOCRACY. All remaining regime years are coded as MIXED NONDEMOCRACY; this category includes all country-years that are not democratic, interregna,

53. I follow Schultz in restricting the sample to "originator dyads," where both states were involved in the dispute from its first day. I constructed the data set using EUGene software, version 3.1; see Bennett and Stam 2000.

54. Changing the democracy threshold to be more inclusive does not substantively affect the results report below. 
or monarchy, but are nevertheless omitted from Geddes's coding. ${ }^{55}$ Table 2 depicts the overall distribution of country-years of regime types in the 1945-99 period, constructed using the Geddes coding and Polity IV. The most common regime types are DEMOCRACIES, NONDEMOCRATIC INTERREGNA, PERSONALIST regimes, and SINGLE-PARTY regimes, while stable MILITARY regimes and DYNASTIC MONARCHIES are among the less common regime types.

TABLE 2. Distribution of regime types worldwide by country-year, 1946-99

\begin{tabular}{lcc}
\hline Regime type & Frequency & Percentage \\
\hline & & \\
\hline DEMOCRACY & 1,862 & 27.8 \\
NONDEMOCRATIC INTERREGNA & 1,153 & 17.2 \\
PERSONALIST & 1,102 & 16.4 \\
SINGLE-PARTY & 909 & 13.5 \\
MIXED NONDEMOCRACY & 689 & 10.3 \\
NONDYNASTIC MONARCHY & 304 & 4.5 \\
NEW DEMOCRACY & 252 & 3.8 \\
MILITARY & 169 & 2.5 \\
DYNASTIC MONARCHY & 157 & 2.3 \\
HYBRID MILITARY/SINGLE-PARTY & 114 & 1.7 \\
Total & 6,711 & 100 \\
\end{tabular}

Table 3 provides a different analysis of the data, depicting the rates of target reciprocation when authoritarian regimes are disaggregated. Recall that targets should resist at lower rates against challengers with higher ability to generate audience costs. Table 3 reveals that although democratic challengers meet lower rates of resistance when compared to all nondemocracies, the supposed democratic advantage disappears when nondemocracies are differentiated from each other. Reciprocation rates of single-party regimes are nearly as low as those of democracies, while the reciprocation rates of mixed nondemocracies are actually the lowest of any regime type. Military regimes and dynastic monarchies follow. Nondynastic monarchies, personalist regimes, new democracies, and nondemocratic interregna feature the highest reciprocation rates, suggesting that when these regimes make challenges, their threats are perceived to be less credible by the target states. Preliminary evi-

55. "Mixed nondemocracy" include countries that are not considered democratic according to Polity IV but are also neither monarchies nor coded by Geddes. In practice, this category includes the post-Soviet republics, Iran after the fall of the Shah (sixty-seven observations), South Africa under apartheid (twenty observations), Russia after the fall of the Soviet Union (twenty-two observations), and a host of countries that while not considered democratic by Polity IV, were not autocratic enough to merit inclusion in Geddes's study of authoritarian regimes. Of the 1,582 post-1945 MIDs in the sample, 205 involve challengers that were mixed nondemocracies. 
dence therefore confirms that there is significant variation in nondemocracies' ability to signal, and it is consistent with the hypothesis that democracies do not have an advantage over nondemocracies in which elites can visibly coordinate.

TABLE 3. Target reciprocation rates by regime type of challenger, 1946-99

\begin{tabular}{ll}
\hline Challenger regime type & Reciprocation rate \\
\hline DEMOCRACY & $.41(358)$ \\
SINGLE-PARTY & $.44(272)$ \\
HYBRID MILITARY/SINGLE-PARTY & $.44(9)$ \\
MILITARY & $.55(44)$ \\
DYNASTIC MONARCHY & $.53(15)$ \\
MIXED NONDEMOCRACY & $.33(206)$ \\
NONDYNASTIC MONARCHY & $.58(38)$ \\
NONDEMOCRATIC INTERREGNA & $.57(259)$ \\
PERSONALIST & $.61(335)$ \\
NEW DEMOCRACY & $.65(46)$ \\
Total & $0.49(1,582)$ \\
\hline
\end{tabular}

Note: The number of observations is in parentheses.

The next step is to ensure that the relationships suggested in Table 3 are not due to confounding variables such as relative power, military capabilities, geographic proximity, or the issues at stake in the dispute. A binary dependent variable model such as logistic regression allows one to control for variables correlated with regime type that may also affect reciprocation rates. Table 4 reports the results of a logistic regression of target reciprocation on various predictor variables. Along with the regime type variables, I include several measures of the distribution of power within the crisis dyad, including the initiator's share of capabilities and whether each side is a major or minor power; a variable indicating whether the states are contiguous on land or across less than 400 miles of water; whether the two states are part of a formal alliance; a weighted measure of the similarity of the two states' alliances; how closely aligned each state is with the current leader of the international system (to give an indication of each state's evaluation of the "status quo"); and finally, the issues at stake in the dispute. ${ }^{56}$ The Appendix contains detailed descriptions of each control variable.

Model 1 replicates the conventional finding about audience costs for 1946$99 .{ }^{57}$ The results indicate that, based on the typical specification, states targeted by stable democratic challengers are significantly less likely to reciprocate dis-

56. All variables generated using EUGene software, version 3.1, Bennett and Stam 2000.

57. The result also holds for the 1816-1984 period analyzed by Schultz (2001a). 
TABLE 4. Reciprocation by regime type of challenger, 1946-99

\begin{tabular}{|c|c|c|c|c|}
\hline & $\begin{array}{c}\text { (Model 1) } \\
\text { Nondemocracies } \\
\text { are base category }\end{array}$ & $\begin{array}{c}(\text { Model } 2) \\
\text { Democracies } \\
\text { are base category }\end{array}$ & $\begin{array}{c}\text { (Model 3) } \\
\text { Bilateral } \\
\text { disputes only }\end{array}$ & $\begin{array}{c}\text { (Model 4) } \\
\text { Nondemocracies } \\
\text { only; personalists } \\
\text { base category }\end{array}$ \\
\hline \multicolumn{5}{|l|}{ Initiator regime variables } \\
\hline DEMOCRATIC (>2 years) & $\begin{array}{l}-0.40 \\
(0.17)^{*}\end{array}$ & & & \\
\hline PERSONALIST & & $\begin{array}{l}0.91 \\
(0.21) * *\end{array}$ & $\begin{array}{l}0.71 \\
(0.22) * *\end{array}$ & \\
\hline SINGLE-PARTY & & $\begin{array}{c}-0.02 \\
(0.24)\end{array}$ & $\begin{array}{c}0.22 \\
(0.26)\end{array}$ & $\begin{array}{l}-0.96 \\
(0.24) * *\end{array}$ \\
\hline MILITARY & & $\begin{array}{c}0.48 \\
(0.35)\end{array}$ & $\begin{array}{c}0.34 \\
(0.35)\end{array}$ & $\begin{array}{c}-0.40 \\
(0.35)\end{array}$ \\
\hline HYBRID & & $\begin{array}{c}0.29 \\
(0.97)\end{array}$ & $\begin{array}{c}0.58 \\
(1.06)\end{array}$ & $\begin{array}{c}-0.65 \\
(1.02)\end{array}$ \\
\hline MIXED NONDEMOCRACY & & $\begin{array}{c}0.02 \\
(0.24)\end{array}$ & $\begin{array}{r}-0.06 \\
(0.24)\end{array}$ & $\begin{array}{l}-0.75 \\
(0.23) * *\end{array}$ \\
\hline DYNASTIC MONARCHY & & $\begin{array}{c}-0.04 \\
(0.60)\end{array}$ & $\begin{array}{c}-0.16 \\
(0.62)\end{array}$ & $\begin{array}{c}-0.98 \\
(0.58)\end{array}$ \\
\hline NONDYNASTIC MONARCHY & & $\begin{array}{c}0.42 \\
(0.40)\end{array}$ & $\begin{array}{c}0.43 \\
(0.42)\end{array}$ & $\begin{array}{r}-0.53 \\
(0.39)\end{array}$ \\
\hline NONDEMOCRATIC INTERREGNA & & $\begin{array}{c}0.49 \\
(0.21)^{*}\end{array}$ & $\begin{array}{l}0.55 \\
(0.22)^{*}\end{array}$ & $\begin{array}{r}-0.35 \\
(0.18)\end{array}$ \\
\hline NEW DEMOCRACY & & $\begin{array}{c}0.77 \\
(0.34) *\end{array}$ & $\begin{array}{c}0.66 \\
(0.36)\end{array}$ & \\
\hline POLITY SCORE & & & & $\begin{array}{r}-0.02 \\
(0.01)\end{array}$ \\
\hline \multicolumn{5}{|l|}{ International controls } \\
\hline MAJOR-MAJOR & $\begin{array}{c}-0.18 \\
(0.29)\end{array}$ & $\begin{array}{c}0.25 \\
(0.31)\end{array}$ & $\begin{array}{c}-0.11 \\
(0.35)\end{array}$ & $\begin{array}{c}0.38 \\
(0.39)\end{array}$ \\
\hline MINOR-MAJOR & $\begin{array}{c}-0.01 \\
(0.23)\end{array}$ & $\begin{array}{c}0.08 \\
(0.23)\end{array}$ & $\begin{array}{c}0.10 \\
(0.24)\end{array}$ & $\begin{array}{c}0.25 \\
(0.27)\end{array}$ \\
\hline MAJOR-MAJOR & $\begin{array}{c}0.20 \\
(0.20)\end{array}$ & $\begin{array}{c}0.53 \\
(0.23) *\end{array}$ & $\begin{array}{c}0.36 \\
(0.26)\end{array}$ & $\begin{array}{c}0.43 \\
(0.29)\end{array}$ \\
\hline INITIATOR CAPABILITIES SHARE & $\begin{array}{c}-0.19 \\
(0.23)\end{array}$ & $\begin{array}{c}-0.20 \\
(0.23)\end{array}$ & $\begin{array}{c}-0.25 \\
(0.25)\end{array}$ & $\begin{array}{c}-0.34 \\
(0.27)\end{array}$ \\
\hline CONTIGUITY & $\begin{array}{c}0.53 \\
(0.14) * *\end{array}$ & $\begin{array}{l}0.58 \\
(0.14) * *\end{array}$ & $\begin{array}{l}0.49 \\
(0.16)^{* *}\end{array}$ & $\begin{array}{l}0.77 \\
(0.17) * *\end{array}$ \\
\hline ALLY & $\begin{array}{c}-0.11 \\
(0.16)\end{array}$ & $\begin{array}{c}-0.13 \\
(0.16)\end{array}$ & $\begin{array}{c}-0.08 \\
(0.18)\end{array}$ & $\begin{array}{c}-0.29 \\
(0.18)\end{array}$ \\
\hline ALLIANCE PORTFOLIO SIMILARITY & $\begin{array}{c}0.26 \\
(0.21)\end{array}$ & $\begin{array}{c}0.34 \\
(0.21)\end{array}$ & $\begin{array}{l}0.53 \\
(0.24)^{*}\end{array}$ & $\begin{array}{c}0.34 \\
(0.27)\end{array}$ \\
\hline STATUS QUO EVALUATION INITIATOR & $\begin{array}{c}0.13 \\
(0.28)\end{array}$ & $\begin{array}{c}0.04 \\
(0.30)\end{array}$ & $\begin{array}{c}0.24 \\
(0.34)\end{array}$ & $\begin{array}{c}0.02 \\
(0.41)\end{array}$ \\
\hline STATUS QUO EVALUATION TARGET & $\begin{array}{c}-0.17 \\
(0.27)\end{array}$ & $\begin{array}{c}-0.15 \\
(0.28)\end{array}$ & $\begin{array}{c}-0.31 \\
(0.31)\end{array}$ & $\begin{array}{r}-0.26 \\
(0.35)\end{array}$ \\
\hline \multicolumn{5}{|l|}{ Revision type } \\
\hline TERRITORY & $\begin{array}{c}0.28 \\
(0.17)\end{array}$ & $\begin{array}{c}0.24 \\
(0.17)\end{array}$ & $\begin{array}{c}0.03 \\
(0.18)\end{array}$ & $\begin{array}{c}0.12 \\
(0.20)\end{array}$ \\
\hline GOVERNMENT OR REGIME & $\begin{array}{c}0.04 \\
(0.28)\end{array}$ & $\begin{array}{c}-0.01 \\
(0.27)\end{array}$ & $\begin{array}{c}-0.38 \\
(0.35)\end{array}$ & $\begin{array}{c}0.14 \\
(0.31)\end{array}$ \\
\hline POLICY & $\begin{array}{l}-1.30 \\
(0.15) * *\end{array}$ & $\begin{array}{l}-1.29 \\
(0.15)^{* *}\end{array}$ & $\begin{array}{l}-1.45 \\
(0.16)^{* *}\end{array}$ & $\begin{array}{l}-1.34 \\
(0.17) * *\end{array}$ \\
\hline OTHER & $\begin{array}{l}-1.35 \\
(0.33) * *\end{array}$ & $\begin{array}{l}-1.35 \\
(0.33)^{* *}\end{array}$ & $\begin{array}{l}-1.58 \\
(0.36)^{* *}\end{array}$ & $\begin{array}{l}-1.25 \\
(0.37)^{* *}\end{array}$ \\
\hline Constant & $\begin{array}{c}0.19 \\
(0.26)\end{array}$ & $\begin{array}{c}-0.36 \\
(0.31)\end{array}$ & $\begin{array}{c}-0.33 \\
(0.33)\end{array}$ & $\begin{array}{c}0.46 \\
(0.35)\end{array}$ \\
\hline Observations & 1,582 & 1,582 & 1,276 & 1,222 \\
\hline
\end{tabular}

Notes: Robust standard errors, clustered by dispute, are in parentheses. *significant at $5 \%$; $*$ significant at $1 \%$. 
putes than states targeted by nondemocratic challengers. Analogous results in the existing literature have provided the main evidence for a democratic signaling advantage.

In all models, control variables perform consistently with previous work. Geographically contiguous targets are more likely to reciprocate, and disputes about policy-related issues are less likely to be reciprocated than disputes about other issue types.

I now test whether these results change when nondemocracies are treated not as a homogenous group, but rather as distinct regime types according to the criteria outlined above. Consistent with the approach taken above, I add new dummy variables indicating whether or not the initiator was a personalist, military, singleparty, hybrid military/single-party regime, nondemocratic interregnum, new democracy, mixed regime, dynastic monarchy, or nondynastic monarchy. ${ }^{58}$ Consolidated democratic regimes are now the base category; coefficients should be interpreted in relation to the probability that a country challenged by a stable democracy resists the challenger's threat. The results of key specifications are reported in Table $4 .{ }^{59}$

Recall that based on the logic of audience costs, PERSONALIST regimes, NONDEMOCRATIC INTERREGNA, NEW DEMOCRACIES, and NONDYNASTIC MONARCHIES were hypothesized to have a lower ability to generate audience costs than other regime types. The statistical analysis indicates that targets are indeed significantly more likely to resist personalist regimes, new democracies, and nondemocratic interregna. The coefficient on NONDYNASTIC MONARCHIES is also positive, though not significant. In contrast, regimes that were hypothesized to more easily generate audience costs, including SINGLE-PARTY regimes, MILITARY regimes, DYNASTIC MONARCHIES, and MIXED NONDEMOCRACIES, are statistically no more likely to face reciprocation than DEMOCRACIES. The coefficients on SINGLE-PARTY regimes, MIXED NONDEMOCRACIES, and DYNASTIC MONARCHIES and are in fact negative in some specifications. ${ }^{60}$ Moreover, the central results are consistent when the sample of disputes is restricted to bilateral disputes only (Model 3 in Table 4). ${ }^{61}$ The

58. Geddes (2003) codes a number of regimes as hybrids between personalist regimes and military or single-party regimes. Consistent with the audience costs logic, it seemed appropriate to treat these hybrids as personalist regimes, though differentiating between hybrid personalist and "pure" personalist regimes does not affect the results.

59. Tables of further specifications are available on the author's Web site at /www.stanford.edu/ $\sim$ jweeks/research $\rangle$.

60. See additional tables at $\langle w w w . s t a n f o r d . e d u / \sim$ jweeks/research $\rangle$, including specifications that include a measure of the size of the winning coalition. A smaller winning coalition might capture the leader's ability to impede coordination by restricting appointments to high office. I find that larger winning coalitions do indeed significantly predict lower reciprocation when it is the only regime type variable included in the analysis. However, when the regime type variables coded for this article are also included in the model, the winning coalition coefficient is no longer significant, and the findings remain consistent with the results presented here.

61. The $\mathrm{p}$-value for the coefficient on new democracies in bilateral disputes is .06, compared to .02 in the full samples. 
data confirm the hypothesis that many nondemocracies can make credible threats against other states because of domestic audience costs their leaders would otherwise incur from backing down. Most nondemocracies are no more likely than democracies to face military resistance from targets. Only NONDEMOCRATIC INTERREGNA, PERSONALIST regimes, and NEW DEMOCRACIES are significantly more likely to face reciprocation than democracies. Moreover, the coefficient on nondynastic monarchies is also in the anticipated (positive) direction, though it is not statistically significant.

It is also useful to assess the substantive effect of regime type on the probability that a target resists. Using Clarify, I estimate the probability that the target state reciprocates conditional on the regime type of the challenger. ${ }^{62}$ I set all control variables to their mean or median values, and consider a situation in which the issue at stake is a policy-the most common revision type in the data set. Table 5 presents the predicted probability of reciprocating against an initiator of the given regime type.

TABLE 5. Predicted probability of reciprocation by regime type of challenger

\begin{tabular}{lcc}
\hline Initiator regime type & $\begin{array}{c}\text { Predicted probability } \\
\text { of target reciprocation }\end{array}$ & $\begin{array}{c}95 \text { percent } \\
\text { confidence interval }\end{array}$ \\
\hline DEMOCRACY & .27 & $(.21, .34)$ \\
SINGLE-PARTY & .26 & $(.18, .35)$ \\
MIXED NONDEMOCRACY & .27 & $(.20, .37)$ \\
MILITARY & .37 & $(.23, .53)$ \\
CYNASTIC MONARCHY & .28 & $(.11, .52)$ \\
NONDYNASTIC MONARCHY & .36 & $(.21, .54)$ \\
AUTOCRATIC INTERREGNA & .37 & $(.29, .46)$ \\
NEW DEMOCRACY & .44 & $(.29, .60)$ \\
PERSONALIST & .48 & $(.40, .55)$ \\
\hline
\end{tabular}

Notes: All continuous variables are set at their mean, and all dichotomous variables are set to their median values. The revision type is set to "political," since this is the most common revision type in the data set. The patterns are consistent across other revision types, as well. All estimates are calculated using Clarify.

DEMOCRACIES, SINGLE-PARTY regimes, MIXED NONDEMOCRACIES, and DYNASTIC MONARCHIES face the lowest estimated reciprocation rates, with predicted probabilities of reciprocation of around .27 each. Military regimes follow, with reciprocation probabilities around .37 , though the confidence interval contains the point estimates for the first four regimes. PERSONALIST regimes and NEW DEMOCRACIES, in contrast, face the highest estimated rates of resistance; their threats face 
a predicted probability of resistance of .48 and .44 respectively. PERSONALIST regimes, therefore, are approximately 1.8 times as likely to face reciprocation as democratic, single-party, and mixed nondemocratic regimes. NEW DEMOCRACIES are 1.6 times as likely to face reciprocation as stable democracies. Moreover, the confidence intervals of most nondemocratic regime types overlap with the estimated democratic reciprocation rate; only AUTOCRATIC INTERREGNA and PERSONALIST regimes are statistically distinguishable from democratic initiators with 95 percent confidence.

Finally, it is worth addressing the robustness of the results, as well as alternative interpretations of the findings. First, I subjected the results to additional specifications to ensure that the results are not being driven by other variables correlated with regime type. For example, I control for measures of economic development to ensure that personalist regimes were not proxying for "weak" regimes, by adding per capita energy consumption to the analysis. ${ }^{63}$ It might also be the case that personalist regimes tend to challenge types of regimes that are unusually prone to reciprocate. I therefore estimate the model controlling not only for the challenger's regime type but also for the target's regime type. The regime type findings are not affected.

Another robustness check is to ensure that individual states are not driving the results. In some cases, individual states make up a large proportion of states in their regime category. I exclude high-conflict countries such as the Soviet Union, China, Iraq, Syria, and North Korea, Thailand, the United States, India, and Israel both separately and in various combinations that could potentially affect the results. The results are robust to such exclusions. ${ }^{64}$

An additional question is whether regime categories simply capture variation in levels of democracy. One possibility is that personalist regimes are merely the "most autocratic" of the autocracies; the conventional wisdom would predict that the most autocratic regimes should be least able to signal. To assess this possibility, I take two approaches. First, I include Polity scores in the logit model to see whether challengers' Polity scores explain variation in reciprocation. This estimation is reported in Model 4 in Table 4. I estimate the model only on the sample of nondemocratic states, with personalist regimes as the base category, since the main question is whether Polity scores explain variation within autocracies. ${ }^{65}$ Model 4 in Table 4 indicates that level of democracy does not explain variation in target reciprocation between nondemocracies; some other factor must be driving the differences between regime categories. Next, Table 6 shows the average Polity score by regime category within the sample. Military regimes have slightly less autocratic Polity scores than other regimes, though the 95 percent confidence intervals

63. Peceny, Beer, and Sanchez-Terry 2002.

64. See $\langle$ www.stanford.edu/ jweeks/research $\rangle$ for replication code.

65. Moreover, including the Polity score in an estimation that includes the whole sample leads to problems of collinearity because the DEMOC variable is correlated with Polity scores at .79. 
of single-party, hybrid, and monarchical regimes overlap with each other. Personalist regimes are not substantially more autocratic than most other nondemocratic regime types.

A related concern is that the personalist variable is actually picking up measurement error in the relative military capabilities data. Available measures of capabilities are well known to be imperfect. Since personalist regimes are often secretive, it could be that estimates of personalist regimes' military capabilities are biased upward in comparison to other regime categories. Consistent with that line of reasoning, Peceny, Beer, and Sanchez-Terry, following Quinlivan, argue that personalist leaders are particularly wary of military coups, and that "coupproofing" the regime requires leaders to weaken the military apparatus. ${ }^{66}$ The inability of personalist states to induce their targets to acquiesce might therefore be because personalist regimes tend to be weaker, rather than less able to signal. But this would be a problem only if capabilities share were an important predictor of reciprocation rates. In fact, INITIATOR CAPABILITIES SHARE is not a significant predictor of reciprocation when the models are estimated on a sample that excludes personalist regimes (thus, on a sample of states with potentially less biased capabilities measures). ${ }^{67}$ Since INITIATOR CAPABILITIES SHARE does not predict reciprocation rates, it seems unlikely that biased measurement of capabilities is driving the results.

TABLE 6. Average polity scores in sample by regime type, 1946-99

\begin{tabular}{lrcc}
\hline Regime type & $N$ & Mean polity & $\begin{array}{c}95 \text { percent } \\
\text { confidence interval }\end{array}$ \\
\hline DEMOCRACY & 348 & 9.14 & $(9.01,9.29)$ \\
NEW DEMOCRACY & 46 & 8.21 & $(7.89,8.54)$ \\
MILITARY & 44 & -4.43 & $(-5.81,-3.06)$ \\
PERSONALIST & 335 & -7.29 & $(-7.55,-7.03)$ \\
SINGLE-PARTY & 272 & -6.96 & $(-7.22,-6.69)$ \\
HYBRID MILITARY/SINGLE-PARTY & 9 & -7.33 & $(-9.57,-5.09)$ \\
DYNASTIC MONARCHY & 15 & -9.60 & $(-10.18,-9.02)$ \\
NONDYNASTIC MONARCHY & 38 & -7.40 & $(-8.54,-6.20)$ \\
AUTOCRATIC INTERREGNA & 257 & -2.91 & $(-3.45,-2.36)$ \\
MIXED NONDEMOCRACY & 206 & -1.14 & $(-1.85,-0.43)$ \\
Total & 1,570 & -1.55 & \\
\hline
\end{tabular}

66. See Peceny, Beer, and Sanchez-Terry 2002; and Quinlivan 1999.

67. In fact, the finding that the initiator's share of capabilities does not predict reciprocation rates supports the prediction of Fearon's 1994 model. 
Finally, the high reciprocation rate to personalist challengers could indicate that personalist regimes have lower "values for war," not higher audience costs. ${ }^{68}$ Schultz points out that states believed to face higher costs for war will face higher rates of resistance by their targets. ${ }^{69}$ An alternative interpretation of these findings is therefore that personalist regimes who have initiated a crisis find war relatively less attractive than other regime types. A variant of this argument builds on Andreski's insight: regimes that depend on the military to maintain power find it relatively less attractive to send their forces abroad, even if the military is equally strong as in other regime types. ${ }^{70}$ Thus, personalist leaders, many of whom rely on the military to quell domestic opposition, might want to keep their armed forces close at hand, making war-fighting comparatively more costly. But the opposite hypothesis might also be defended: it is often thought that militaries place a high value on fighting wars and, therefore, sending the military off to war might either divert its attention from a coup or make it lend even more support to the regime. Moreover, personalist leaders, who are relatively immune to threats from elites or the population, would be less sensitive to the human costs of fighting than other regime types, mitigating the costs of war even if they are reluctant to deploy their forces. Thus, higher costs for war in personalist regimes are unlikely to explain the findings reported here.

\section{Conclusion}

The conventional theory that democracies are systematically superior to nondemocracies in generating audience costs underestimates the difficulties most autocrats face in maintaining power. The literature on audience costs has taken a narrow view of accountability-one that focuses primarily on electoral procedures for removing leaders. This article argues that most nondemocracies do in fact meet the basic requirements for generating politically significant audience costs. Only when the leader can use monitoring and punishment to prevent elite coordination, or when foreign decision makers cannot observe the possibility of such coordination, can states not generate audience costs. My statistical analysis of behavior in MIDs shows that threats by democracies are not significantly more credible than threats by most autocratic regimes. Personalist regimes, new democracies, and unstable nondemocracies, on the other hand, are much more likely to face resistance from the targets of their threats.

The evidence in this article not only supports the existence of autocratic audience costs but also casts doubt on alternative theories about the effects of domestic politics on international relations. Schultz has argued that public, legitimate, and institutionalized party competition helps states credibly reveal resolve in cri-

68. Quinlivan 1999.

69. Schultz 2001a.

70. Andreski 1980. 
ses. ${ }^{71}$ This theory cannot, however, explain my finding that single-party regimes can generate threats that are as credible as those issued by democracies. The analysis therefore indicates that autocratic regimes can attain international credibility even when the majority of the population is formally excluded from political participation.

The findings also suggest that much remains to be learned about differences in domestic politics across nondemocracies, and how such variation affects international relations. If, as I argue in this article, some autocratic elites can truly hold leaders accountable, one might expect nondemocracies to vary in the extent to which they punish leaders for other foreign policy failures. ${ }^{72}$ Scholars should therefore investigate the effects of regime type on questions such as the initiation of wars, success in wars, the initiation of militarized disputes, the credibility of promises made in international treaties, and the sacrifices states will make to maintain friendly relations with other countries. Moreover, the identity and interests of elite audiences - and therefore the sorts of actions for which they might punish leaders-are poorly understood. In this article I argue that elites do have incentives to punish leaders who back down. However, elite preferences over foreign policy may vary systematically across nondemocracies, influencing when domestic groups will be motivated to hold leaders accountable. For example, even elites in regimes that can hold the leader accountable may be indifferent to some issues that concern democratic decision makers, including wartime casualties and economic deprivation, open trade, international norms, or other factors affecting states' decisions about international relations.

The analysis is not only of theoretical importance but also suggests practical implications for policymakers. According to many scholars, uncertainty about other states' intentions significantly increases the likelihood of international conflict. ${ }^{73}$ Under anarchy, states that cannot discern another state's intentions will tend to assume the worst, amassing arms and potentially creating a "security dilemma" that increases distrust and makes conflict more likely ${ }^{74}$ As Fearon points out, however, domestic audience costs can alleviate the security dilemma by increasing states' ability to convey intentions. Just as leaders may generate domestic costs by backing down from a threat, they can also incur costs by reneging on peaceful promises such as commitments not to invade neighboring states. Thus, higher audience costs may alleviate the security dilemma by reducing uncertainty about whether a promise to keep peace is genuine.

Dyads in which both states have high audience costs, therefore, are often hypothesized to be more peaceful in their international relations than other dyads. The conventional wisdom about the relationship between democracy and audience costs supports the view that democratization increases peace, or that "The best hope for

71. Schultz 2001a.

72. Weeks 2007.

73. See, for example, Glaser 1992; and Waltz 1979.

74. Jervis 1978 . 
peace in our world is the expansion of freedom in all the world." 75 However, my analysis suggests that the current focus on democratization as a way to foster international cooperation requires further scrutiny. I find that not only are most nondemocratic regimes as able to generate audience costs as democratic regimes, but that new democracies are significantly more likely than consolidated democratic regimes to evoke a militarized reaction from their opponents. Moreover, nondemocratic interregna-states that have recently undergone regime change but remain below the democratic threshold - are similarly unable to convey resolve. The findings suggest that fostering democratic institutions, especially where they are unlikely to take root, may not ameliorate the security dilemma. Rather, the logic laid out here suggests that leaders and international organizations, rather than focusing only on the spread of mass participatory institutions, might instead encourage more minor reforms within the ruling elite. For example, they might make aid conditional on the leader allowing collective oversight of appointments and security organs. At the very least, policymakers should be hesitant to discourage existing institutional arrangements at the elite level, be they single-party regimes, military juntas, or other regime types, if these arrangements allow elites to hold leaders accountable.

The overall implication of this analysis is that scholars and policymakers misplace attention when they focus on electoral competition and other elements of democracy, rather than theorizing about less normatively appealing forms of political rivalry. Autocratic leaders, while they may exert enormous control over their subjects, are not usually immune from domestic threats to their tenure. The standard dichotomy, therefore, masks important variation between types of authoritarian regimes and may lead to mistaken inferences about the effects of democratic domestic institutions on foreign relations. This analysis shows that by analyzing differences between nondemocratic regimes, one is led to question previous assumptions about the relationship between democracy and international relations. Perhaps more importantly, analyzing the effects of domestic politics in nondemocracies offers a fresh avenue for gaining insights into international behavior.

\section{Appendix}

\section{Regime Type Categories}

\section{Monarchies}

Since Geddes does not code monarchies, I use the Polity IV Xropen variable for "Openness of Executive Recruitment" and define monarchies as country-years where XROPEN $<4$ $\&$ XROPEN $>0$. This identifies all regimes with hereditary succession. I code dynastic vs. nondynastic monarchies according to Herb. ${ }^{76}$

75. President George W. Bush, Second Inaugural Address, 20 January 2005. Text available at $\langle$ http://www.whitehouse.gov/inaugural/〉.

76. Herb 1999, 8 . 
TABLE A1. Control variable definitions

MAJOR-MINOR POWER DYADS

INITIATOR CAPABILITIES SHARE

CONTIGUITY

ALLY

ALLIANCE PORTFOLIO SIMILARITY

STATUS QUO EVALUATION INITIATOR/TARGET

REVISION TYPE
These are dummy variables indicating whether the crisis dyad consists of an (initiator-target) major-major, minor-major, or major-minor power dyad. Minor-minor power dyads are the reference category.

This variable was generated using the Correlates of War National Capabilities Index. INITIATOR CAPABILITIES SHARE is the initiator's score on the capabilities index divided by the sum of total capabilities in the dyad.

A dummy variable indicating that the two states are either contiguous on land or across 400 miles of water at most.

Dummy variable coded 1 if the two states share a defense pact, neutrality agreement, or formal entente.

Weighted global S score between the two states in the dyad.

$\mathrm{S}$ score between the country and the system leader using countries in the "relevant region."

Dummy variables indicating whether the issue at stake involved territory, government or regime, policy, or "other" revision according to the MID dataset. The reference category contains crises with no specific revision identified.

Source: Generated using EUGene v. 3.1 (Bennett and Stam 2000) unless otherwise noted.

\section{Pure Versus Hybrid Personalist Regimes}

Geddes codes regimes as "hybrids" when they exhibit characteristics of more than one regime type. The logic I develop in this article focuses on whether the leader controls appointments and the intelligence and security apparatus. In my analysis, I therefore place hybrid regimes with a "personalist" component in the personalist category because leaders of these regimes, like pure personalist leaders, are more likely than other regimes to control these aspects of the state. Treating hybrid personalist regimes and purely personalist regimes as separate categories does not affect the central findings.

\section{References}

Anderson, Lisa. 1991. Absolutism and the Resilience of the Monarchy in the Middle East. Political Science Quarterly 106 (1):1-15.

Andreski, Stanislav. 1980. On the Peaceful Disposition of Military Dictatorships. Journal of Strategic Studies 3 (3):3-10.

Bennett, D. Scott, and Allan C. Stam. 2000. EUGene: A Conceptual Manual. International Interactions 26 (2):179-204.

Bratton, Michael, and Nicolas van de Walle. 1994. Neopatrimonial Regimes and Political Transitions in Africa. World Politics 46 (4):453-89. 
1997. Democratic Experiments in Africa: Regime Transitions in Comparative Perspective. Cambridge: Cambridge University Press.

Bueno de Mesquita, Bruce, James D. Morrow, Randolph M. Siverson, and Alastair Smith. 1999. An Institutional Explanation of the Democratic Peace. American Political Science Review 93 (4):791-807.

Bueno de Mesquita, Bruce, Alastair Smith, Randolph M. Siverson, and James D. Morrow. 2003. The Logic of Political Survival. Cambridge, Mass.: MIT Press.

Chehabi, H. E., and Juan J. Linz. 1996. Sultanistic Regimes. Baltimore: Johns Hopkins University Press.

Chiozza, Giacomo, and H. E. Goemans. 2004. International Conflict and the Tenure of Leaders: Is War Still "Ex Post" Inefficient? American Journal of Political Science 48 (3):604-19.

Eyerman, Joe, and Robert A. Hart Jr. 1996. An Empirical Test of the Audience Cost Proposition: Democracy Speaks Louder Than Words. Journal of Conflict Resolution 40 (4):597-616.

Fearon, James D. 1994. Domestic Political Audiences and the Escalation of International Disputes. American Political Science Review 88 (3):577-92.

Geddes, Barbara. 1999. Authoritarian Breakdown: Empirical Test of a Game-Theoretic Argument. Paper presented at the 95th Annual Meeting of the American Political Science Association, September, Atlanta.

- 2003. Paradigms and Sandcastles: Theory Building and Research Design in Comparative Politics. Ann Arbor: University of Michigan Press.

Gelpi, Christopher F., and Michael Griesdorf. 2001. Winners or Losers: Democracies in International Crises, 1918-1994. American Political Science Review 95 (3):633-47.

Ghosn, Faten, Glenn Palmer, and Stuart Bremer. 2004. The MID3 Data Set, 1993-2001: Procedures, Coding Rules, and Description. Conflict Management and Peace Science 21 (2):133-54.

Glaser, Charles. 1992. Political Consequences of Military Strategy: Expanding and Refining the Spiral and Deterrence Models. World Politics 44 (4):497-538.

Goemans, Hein E. 2000. War and Punishment: The Causes of War Termination and the First World War. Princeton, N.J.: Princeton University Press.

Guisinger, Alexandra, and Alastair Smith. 2002. Honest Threats: The Interaction of Reputation and Political Institutions in International Crises. Journal of Conflict Resolution 46 (2):175-200.

Haber, Stephen. 2006. Authoritarian Government. In The Oxford Handbook of Political Economy, edited by Barry R. Weingast and Donald Wittman, 693-707. New York: Oxford University Press.

Herb, Michael. 1999. All in the Family: Absolutism, Revolution, and Democracy in the Middle Eastern Monarchies. Albany: State University of New York Press.

Jervis, Robert. 1978. Cooperation Under the Security Dilemma. World Politics 30:167-214.

Jones, Daniel M., Stuart A. Bremer, and J. David Singer. 1996. Militarized Interstate Disputes, 18161992. Conflict Management and Peace Science 15 (2):163-213.

Kinne, Brandon J. 2005. Decision Making in Autocratic Regimes: A Poliheuristic Perspective. International Studies Perspectives 6 (1):114-28.

Kuran, Timur. 1991. Now out of Never: The Element of Surprise in the East European Revolution of 1989. World Politics 44 (1):7-48.

Linz, Juan J., and Alfred Stepan. 1996. Problems of Democratic Transition and Consolidation: Southern Europe, South America, and Post-communist Europe. Baltimore: Johns Hopkins University Press.

Mansfield, Edward, and Jack Snyder. 2005. Electing to Fight: Why Emerging Democracies Go to War. Cambridge, Mass.: MIT Press.

Marshall, Monty G., and Keith Jaggers. 2002. POLITY IV Project: Political Regime Characteristics and Transitions, 1800-2002: Dataset Users' Manual, University of Maryland, College Park.

McGillivray, Fiona, and Alastair Smith. 2000. Trust and Cooperation Through Agent-Specific Punishments. International Organization 54 (4):809-24.

Menaldo, Victor. 2006. Dictators as Constitution-Makers? Self-Enforcing Constraints in Authoritarian Regimes. Unpublished manuscript, Stanford University, Stanford, Calif.

Partell, Peter J., and Glenn Palmer. 1999. Audience Costs and Interstate Crises: An Empirical Assessment of Fearon's Model of Dispute Outcomes. International Studies Quarterly 43 (2):389-405. 
Peceny, Mark, and Caroline C. Beer. 2003. Peaceful Parties and Puzzling Personalists American Political Science Review 97 (2):339-42.

Peceny, Mark, Caroline C. Beer, and Shannon Sanchez-Terry. 2002. Dictatorial Peace? American Political Science Review 96 (12):15-26.

Prins, Brandon C. 2003. Institutional Instability and the Credibility of Audience Costs: Political Participation and Interstate Crisis Bargaining, 1816-1992. Journal of Peace Research 40 (1):67-84.

Quinlivan, James T. 1999. Coup-Proofing: Its Practice and Consequences in the Middle East. International Security 24 (2):131-65.

Schelling, Thomas. 1963. The Strategy of Conflict. New York: Oxford University Press.

Schultz, Kenneth A. 1999. Do Democratic Institutions Constrain or Inform? Contrasting Two Institutional Perspectives on Democracy and War. International Organization 53 (2):233-66. 2001a. Democracy and Coercive Diplomacy. New York: Cambridge University Press. 2001b. Looking for Audience Costs. Journal of Conflict Resolution 45 (1):32-60.

Slantchev, Branislav L. 2006. Politicians, the Media and Domestic Audience Costs. International Studies Quarterly 50 (2):445-77.

Smith, Alastair. 1998. International Crises and Domestic Politics. American Political Science Review $92(3): 623-38$.

Tompson, William J. 1991. The Fall of Nikita Khrushchev. Soviet Studies 43 (6):1101-21.

Tomz, Michael, Gary King, and Jason Wittenberg. 2000. Making the Most of Statistical Analyses: Improving Interpretation and Presentation. American Journal of Political Science 44 (2):347-61.

Tomz, Michael, Jason Wittenberg, and Gary King. 2003. CLARIFY: Software for Interpreting and Presenting Statistical Results. Version 2.1. Stanford University, University of Wisconsin, and Harvard University. Available at $\langle$ http://gking.harvard.edu $\rangle$.

Tomz, Michael. 2007. Domestic Audience Costs in International Relations: An Experimental Approach. International Organization 61 (4):821-40.

Waltz, Kenneth. 1979. Theory of International Politics. Reading, Mass.: Addison-Wesley.

Weeks, Jessica L. 2007. Leaders, Accountability, and Foreign Policy in Non-Democracies. Paper presented at the 48th Annual Convention of the International Studies Association, February-March, Chicago.

Weingast, Barry R. 1997. The Political Foundations of Democracy and the Rule of Law. American Political Science Review 91 (2):245-63. 